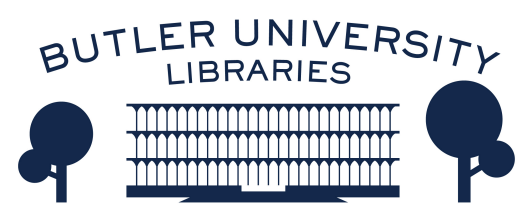

Journal of Hindu-Christian Studies

Volume 22

Article 5

January 2009

\title{
Response to Rambachan's "The Advaita Worldview" and Thatamanil's "The Immanent Divine"
}

Michelle Voss Roberts

Follow this and additional works at: https://digitalcommons.butler.edu/jhcs

Part of the Religion Commons

\section{Recommended Citation}

Roberts, Michelle Voss (2009) "Response to Rambachan's "The Advaita Worldview" and Thatamanil's "The Immanent Divine"," Journal of Hindu-Christian Studies: Vol. 22, Article 5.

Available at: https://doi.org/10.7825/2164-6279.1432

The Journal of Hindu-Christian Studies is a publication of the Society for Hindu-Christian Studies. The digital version is made available by Digital Commons @ Butler University. For questions about the Journal or the Society, please contact cbauman@butler.edu. For more information about Digital Commons @ Butler University, please contact digitalscholarship@butler.edu. 


\title{
Response to Rambachan's The Advaita Worldview and Thatamanil's The Immanent Divine ${ }^{1}$
}

\author{
Michelle Voss Roberts \\ Rhodes College
}

IN light of postcolonial and feminist criticism, it has become good form for scholars to "locate themselves" with regard to their subject matter by laying out their values and presuppositions to the extent possible. Because supposedly "objective" or "neutral" scholarship often reflects hegemonic interests, this practice ideally brings self-awareness about the discourses we carry into the hermeneutical process. Postcolonial discourse since Edward Said's Orientalism (1978) instructs that if Western academics are to continue representing the so-called East, they must at least acknowledge the dominance of Western and Christian presuppositions in this scholarly tradition.

Critics of such unacknowledged prejudices have cited Rudolf Otto's classic comparative work of Meister Eckhart and Śankara (Mysticism East and West, 1932) as an example. In Otto, as in much Orientalist scholarship, Śankara and the East are pantheistic, quietistic, amoral, and detached, with a static brahman and an illusory world. This East provides a foil for the West's activism, morality, dynamic divinity, and acceptance of the world. Richard King writes,
Otto's critique of Advaita Vedānta as detached, amoral and world-denying ... allows him to displace contemporary debates about the status and implications of Eckhart's mystical theology onto an Indian 'screen'. Through this process, Eckhart becomes redeemed or absolved of precisely those characteristics for which he has been so frequently criticized. $^{2}$

Even where East and West overlap as in Eckhart and Sankara, the West is vindicated by stopping just short of the essential pathological features of the non-dualist East.

John Thatamanil and Anant Rambachan's recent works on Advaita do not paint the tradition with such a wide brush. They shade in areas of stark contrast, shed light on misinterpretations, and sketch out new areas for development. Their Advaita looks quite different from Orientalist copies and exports: it is vibrant and alive, and appeals strongly to contemporary audiences in its practical conclusions. The disparity with the shopworn portrait of non-dualism raises questions regarding the values operating behind the scenes, and more importantly, of the origins of these values. How traditional

Michelle Voss Roberts is an assistant professor of Religious Studies at Rhodes College in Memphis, Tennessee. Dr. Voss Roberts has authored articles in feminist and comparative theology in venues including Journal of the American Academy of Religion, Journal of Feminist Studies in Religion, Practical Matters, and Feminist Theology. Her forthcoming book, Dualities: A Theology of Difference (Louisville: Westminster John Knox, 2010), draws upon the theologies of Mechthild of Magdeburg and Lalleśwarī of Kashmir for alternatives to dualistic approaches to divinity, body, and the earth. During a study leave next spring, she will research the Hindu theory on rasas, or aesthetic "tastes," in comparison with the Christian tradition of the spiritual senses. 
are these new Advaitas, and to what extent are they products of Christian interrogation? Given the potential for application of these worldly values to urgent ethical issues (I will address one such potential application below), this is a question I hope to address productively. I begin by "locating" the two theologians more explicitly vis-à-vis the Orientalism debate.

Rambachan is an apologist for a revised understanding of Advaita Vedanta Hinduism. He teaches in a Christian context: Saint Olaf College, where he has taught for some years, is a "college of the church," according to its publicity. "The dialogue partners for contemporary Advaitins have changed," Rambachan writes. "In my case, the circle of dialogue has been extended to include followers of the great traditions of Judaism, Christianity, and Islam." ${ }^{44}$ As a critical and constructive work, The Advaita Worldview confidently answers all of the questions that Christian readers tend to ask of Vedānta. The human dilemma of selfignorance is couched in contemporary terms of existential dissatisfaction and longing for meaning. In contrast to worries about caste, the identity of the self in all becomes the basis for equality. Departing explicitly from parts of the tradition that deny the reality and importance of life in the world, Rambachan reinvigorates scriptural trajectories that view the world as the celebrative overflow of brahman and the product of divine intent. Furthermore, he expands the traditional notion of jivanmukti, liberation while alive, as the basis for worldly activity. His non-dualism lays a strong foundation for equality', created plurality, and agency on behalf of the world.

Thatamanil, a Christian comparative theologian, combats the Orientalist stereotype through his investigation of what he calls "rival conceptions of immanence" in Śankara and the Christian theologian Paul Tillich. $^{5}$ There are many areas of overlap between the two thinkers, including the major barrier to a truly non-dual system that each fails to overcome. This barrier is a residual substantialism that for Śankara must negate the world of experience and for Tillich holds open a tragic rupture between divinity and humanity. Thatamanil's turn to process theology, which has Christian roots, offers an ontology grounded in activity rather than substance. His immanent divine is a creative solution: a process brahman that draws on Robert Neville's notion of creatio ex nihilo and Trinitarian resonances of God as "source, act, and product." Divine activity becomes the very self of human beings: atman is brahman, and this identity is also the basis for affirming activity, agency, and desire in liberated or sanctified persons. The world retains its value and the tragic rupture between God and humanity is overcome.

Are these dynamic, active, worldly nondualisms new vindications of an essentially "Christian" way of thinking? Do Christianity and the West still win out in the end? Is it all just a "logic of the same" in which Advaita Vedānta now mirrors the West positively instead of serving as its photographic negative-in other words, does Advaita now gain credibility because it so closely resembles what the West values?

I think not. At least, as a feminist comparative theologian who also cherishes agency, embodiment, and relation, I hope not. There are several good reasons why Christian theology does not have a monopoly on these values, the first of which is that colonial claims that the East lacks such traits are hardly reliable sources of information. As Ronald Inden puts it, Indology's depiction of India as passive and otherworldly "actually fashioned the ontological space that a British Indian empire occupied. Its leaders would ... inject the rational intellect and world-ordering will that the Indians themselves could not provide."7 Because of the complicity and questionable accuracy of what most of the time was probably well-intentioned scholarship, rereadings of these sources are absolutely necessary.

Second, there is lingering cultural essentialism couched in questions about Christian hegemony. Scholars must put an axe to the remaining roots of this tree. 
World-denying attitudes are far from absent from Christianity in its mystical and raptureexpectant varieties, and the West is not the only source of world-embracing activism. Hindu householder and kingship traditions are just as concerned with worldly affairs as any other culture; and dualist and materialist philosophical schools were Advaita's conversation partners long before Christianity came onto the scene.

Third, going beyond internal Hindu diversity, Advaita Vedānta itself is diverse. Rambachan states, "Advaita is a living tradition." Although some in this tradition have denied the reality of the world, not all have done so. Śankara himself did not view the world as an illusion, says Rambachan; nor did he espouse a doctrine of $m \bar{a} y \bar{a}$ as a material cause of the universe separate from brahman (72-78). Ahistorical essentialism - about the nature of the East in general or Advaita in particular (and the two are often conflated) - must be avoided.

Finally, as in any living tradition, constructive theological projects are warranted. Today many Advaitins speak from the householder rather than (like Śankara) from the renouncer stage of life. This orientation naturally has consequences for the degree of attention one will pay to questions of life in the world and society. Rambachan defends this extension: "While the Upanis)ads and the classical Advaita tradition do not pursue the implications ... for the life of the jivanmukta in society, there is no reason why we should not do so today." There is also no reason, he claims, not to liberate "Advaita from the constraints of a conservative social and ritual order," to "enhance its universality," and to "unleash its potential to challenge the social and religious inequities of caste and gender" (29). New contexts and sensibilities call for new philosophical iterations, and these iterations can be contested with regard to the existence or non-existence of normative parameters of interpretation.

In short, Christianity does not corner the market on worldly agency and social responsibility_an obvious point, admittedly, for most scholars involved in
East-West conversations today. But to avoid the charge that constructive theologians of both traditions are still importing Christian values as "business as usual," we should also make a case for why values like activism, equality, and real worldly diversity are so significant. The status of the external world may serve as an example for how such a defense might proceed. After all, why shouldn't we try to escape the empirical plane? Conversely, why would a jivanmukta or saint embrace it or even follow eco-friendly principles? Because neither theologian discusses an environmental application of their worldly non-dualism, this is the extension of the two works that I would like to pursue.

Here, we return to the issue of the theologian's values and presuppositions. In an inter-religious or inter-cultural situation, the constructive theologian would make the case that concern for the earth is a "reasonable, attractive, compelling, and true" ${ }^{10}$ position for a human being to take. The strongest case would argue for the value of the earth independently of anthropocentric needs, but a purely human perspective might initially be more persuasive: human beings live on the earth, real suffering results from bad ecological habits, and alleviation of suffering is possible through correcting and making amends for these habits. Empirical evidence and the logic of cause and effect can get us this far without recourse to metaphysics; and on such basis we can agree on the importance of the health of the planet for its species.

In order to ask whether non-dual metaphysics can accommodate the challenge of climate crisis, we might borrow and extend Thatamanil's "medical model" in a new direction. Our collective diagnosis very well may be estrangement (as in Tillich) or ignorance about our relationship to the rest of reality (as in Śankara). But the symptoms have spread to our surroundings. We are now painfully aware that ignorance of our connectedness does not affect human beings alone. Actions resulting from avidya imperil everything around us through rising 
global temperatures, droughts, floods, and vanishing ecosystems; ${ }^{11}$ and those whose comfort comes at the expense of this depredation bear its startling karmic weight. At this critical point we may finally be closer to diagnosis and treatment than ever before. We cannot help but acknowledge our profound disease; and we cannot help but perceive how very connected we are to other beings, which is one of the principal insights of the liberated.

Martha Nussbaum, in her employment of the medical analogy, emphasizes the importance of treating the particular case: "just as a good doctor heals case by case, so good medical argument responds to the pupil's concrete situation and needs."12 Effective treatment of the human condition must apply to particular sites of alienation. In relation to the earth this might entail reducing our carbon emissions, cleaning this river or that stream, and coming to the aid of those who now live in uninhabitable areas. How robust a prognosis is possible? I turn again to Tillich and Śankara. Though Tillich captures our tragic enmeshment, Śankara's optimism can motivate us: if we truly understand our deep and dynamic connectedness (non-duality, if you will), will we not treat the beings around us as our very self?

The climate crisis puts a fairly new face on our old problems, and most of the world's religions have ambivalent legacies on ecological issues. ${ }^{13}$ Viable answers are now arising from multiple traditions, which is why. Thatamanil's proposal for a "hybrid Hindu-Christian theology that might appeal to both communities": is quite compelling. ${ }^{14}$ When we "locate ourselves" as' scholars today, we may cite our relationships to multiple religious traditions as relevant sources of our deeply cherished values. Both Hinduism and Christianity have affirmed the reality of the world and the importance of worldly activity; but as exemplified in the new works by Anant Rambachan and John Thatamanil, together they may also invite us to think these questions in new ways.

\section{Notes}

${ }^{1}$ An expanded version of this paper is available in Religious Studies Review (http://www3.interscience. wiley.com/iournal/118 540548/home) as "Worldly Advaita? Limits and Possibilities for an Eco-friendly Nondualism," Religious Studies Review 34:3 (2008): 137-143.

2 Richard King, Orientalism and Religion: Postcolonial Theory, India and 'the Mystic East' (London and New York: Routledge, 1999), 126. http://www stolaf.edu/church/whatis.html, accessed September 1, 2007.

4 Anantanand Rambachan, The Advaita Worldview: God, World, and Humanity (Albany, NY: State University of New York Press, 2006), 5.

5 John J. Thatamanil, The Immanent Divine: God, Creation, and the Human Predicament (Minneapolis: Fortress Press, 2006), xiv.

${ }^{6}$ Ibid., 192.

${ }^{7}$ Ronald Inden, Imagining India (Oxford: Basil Blackwell: 1990), 128.

${ }^{8}$ Rambachan, The Advaita Worldview, 5.

${ }^{9}$ Tbid., 109.

${ }^{10}$ Thatamanil, The Immanent Divine, 173.

${ }^{11}$ For an example of the voluminous literature on this subject, see William McKibben, The End of Nature (New York: Random House, 1989).

${ }^{12}$ Martha C. Nussbaum, The Therapy of Desire: Theory and Practice in Hellenistic Ethics (Princeton, NJ: Princetone University Press, 1994), 46.

${ }^{13}$ A series of major conferences on ecology and religion at Harvard University examined these ambivalent legacies, and the potential ecological insights, of ten major religious traditions. See Christopher Key Chapple and Mary Evelyn Tucker, eds., Religions of the World and Ecology, 10 vols. (Cambridge, Mass.: Harvard University Press, 1997-2003).

${ }^{14}$ Thatamanil, The Immanent Divine, 173.

\section{References}

Chapple, Christopher Key, and Mary Evelyn Tucker, eds. Religions of the World and Ecology. 10 vols. Cambridge, Mass.: Harvard University Press, 1997-2003.

Inden, Ronald Imagining India. Oxford: Basil Blackwell, 1990.

King, Richard. Orientalism and Religion: Postcolonial Theory, India and the Mystic East'. London and 'New York: Routledge, 1999.

McKibben, William. The End of Nature. New York: Random House, 1989. 
Roberts: Response to Rambachan's "The Advaita W orldview" and Thatamanil's "The Immanent Divine"

Nussbaum, Martha C. The Therapy of Desire: Theory and Practice in Hellenistic Ethics. Princeton, NJ: Princeton University Press, 1994.

Otto, Rudolf. Mysticism East and West: A Comparative Analysis of the Nature of Mysticism. Translated by Bertha L. Bracey and Richenda C. Payne. New York: Collier Books, 1962.

Rambachan, Anantanand. The Advaita Worldview: God, World, and Humanity. Albany, NY: State University of New York Press, 2006.

Saint Olaf College Website: http://www.stolaf.edu/church/whatis.html. Accessed September 1, 2007.

Thatamanil, John J. The Immanent Divine: God, Creation, and the Human Predicament. Minneapolis: Fortress Press, 2006. 